\title{
Dead urchin walking: resilience of an arctic Strongylocentrotus to severe skeletal damage
}

\author{
Max Wisshak ${ }^{1} \cdot$ Christian Neumann ${ }^{2}(\mathbb{0}$
}

Received: 8 November 2019 / Revised: 31 January 2020 / Accepted: 13 February 2020 / Published online: 27 February 2020

(c) The Author(s) 2020

\begin{abstract}
The ability of bottom-dwelling marine fauna to repair injured body parts is critical to the survival of individuals from disturbances that inflict wounds. The phylum Echinodermata, in particular, exposes a pronounced ability to regenerate skeletal damages. Regeneration of lost body parts of stellate echinoderms (crinoids, asteroids and ophiuroids) is a well-documented phenomenon, whereas sea urchins (echinoids) have received much less attention. Here we report, for the first time, a field observation on an adult sea urchin of the genus Strongylocentrotus in its natural habitat, exposing severe skeletal damage but remarkable survivorship. The sea urchin was revealed by analysing a time series of seafloor images taken during a lander deployment in a rhodolith bed in the polar waters of northern Spitsbergen, Svalbard. Despite the loss of half the aboral region of the test, including existential organs, the sea urchin continued to move across the seafloor for more than $43 \mathrm{~h}$, thereby escaping another predation attack by a large crab. The observed behaviour is grounded in the peculiarity of the sea urchins' nervous system where locomotion is controlled by a decentralised ectoneural system in the epithelium, large parts of which had remained intact after the traumatic event. Our field observation thus documents initial post-traumatic survival of severe lesions, which is a basic prerequisite for beginning repair processes.
\end{abstract}

Keywords Echinoid $\cdot$ Strongylocentrotus $\cdot$ Predation $\cdot$ Regeneration $\cdot$ Survival $\cdot$ Svalbard

\section{Introduction}

Echinoderms (phylum Echinodermata) possess a striking ability to regenerate soft and skeletal tissues and organs, allowing them to thrive in environments with high injurycausing disturbance rates. These disturbances may be physical (e.g. wave energy, bottom fishing) or biological (predation) in nature. Most studies dealing with regeneration ability in echinoderms focus on the underlying physiological processes with a strong emphasis on arm repair in stellate echinoderms (i.e. crinoids, asteroids and ophiuroids, see Khadra et al. 2018 for a review) which are often subject to sublethal predation (Lawrence and Vasquez 1996). In contrast, regeneration in sea urchins (echinoids) has received far less attention and research has focussed mainly on the

Max Wisshak

max.wisshak@senckenberg.de

1 Marine Research Department, Senckenberg Am Meer, 26382 Wilhelmshaven, Germany

2 Museum für Naturkunde, Leibniz Institute for Evolution and Biodiversity Science, 10115 Berlin, Germany regeneration of their body appendages, especially spines and pedicellariae (Ebert 1967; Heatfield and Travis 1975; Dubois and Ameye 2001). Studies examining the regeneration of the sea urchin test are few (Okada 1926; Ameye and Dubois 1995; Bonasoro et al. 2004) and without exception have been conducted under artificial laboratory conditions. Thus, field observations of sea urchin resilience to severe injuries in their natural habitat are lacking and are here documented for the first time.

During image analysis of a 6-day time series of seafloor images taken via a lander deployment in a rhodolith bed in northern Spitsbergen, an observation was made with regard to a remarkable survivorship of a heavily injured sea urchin. The protagonist is a regular sea urchin of the genus Strongylocentrotus (Strongylocentrotidae), two species of which, $S$. droebachiensis and S. pallidus, thrive in the waters off Svalbard in the Arctic North Atlantic (Gagnon and Gilkinson 1994; Anisimova and Cochrane 2003; Palerud et al. 2004). Both species are similar in morphology and are distinguished by subtle morphological differences (Jensen 1974; Bluhm et al. 1998). Although generally sympatric with an overlap in geographic distribution, $S$. droebachiensis has a 


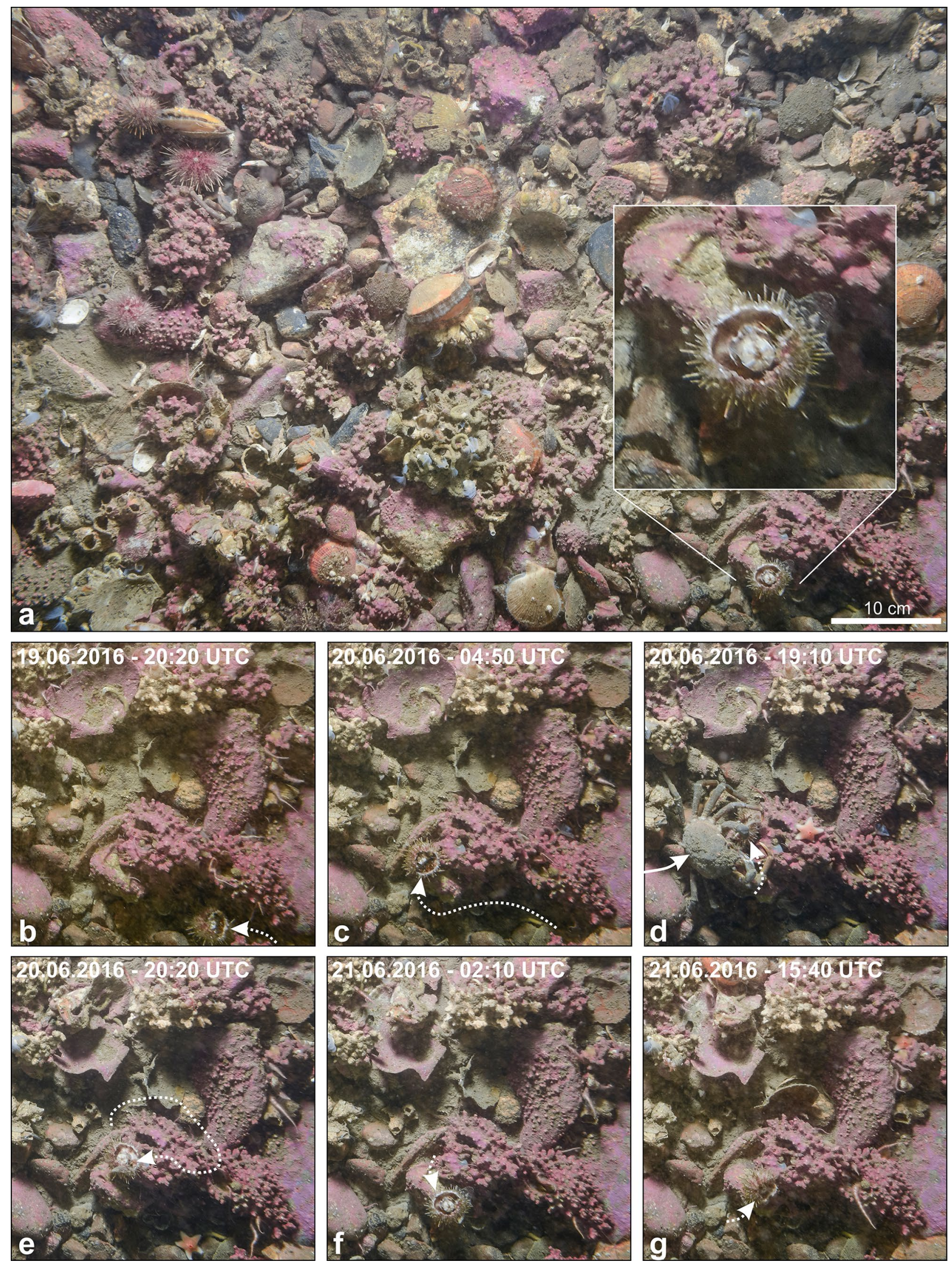


४Fig. 1 A sea urchin of the genus Strongylocentrotus with severe skeletal damage, but still alive and agile, moving across a rhodolith bed in $46 \mathrm{~m}$ water depth in Mosselbukta, Spitsbergen, Svalbard. a. One of the 738 seafloor images with $86 \times 57 \mathrm{~cm}$ field of view, captured by the lander's Ocean Imaging System in 10-min intervals; the inset shows a close-up of the sea urchin protagonist. b-g. Time series illustrating $43 \mathrm{~h}$ and $20 \mathrm{~min}$ in the survival of the sea urchin appearing on the scene already injured (b), but still travelling some distance (c), before suffering another predatory attack by the great spider crab Hyas araneus (d), escape and moving on top of one of the rhodoliths (e), and remaining near that spot but still moving spines and rotating the corona (f) until the last frame of the lander deployment ( $(\mathbf{g})$

preference for littoral waters whereas $S$. pallidus occurs in more northern and/or deeper waters of up to $1600 \mathrm{~m}$ (Bluhm et al. 1998). Given the shallow water depth (46 m), the subject of our observation is most likely $S$. droebachiensis, an abundant key player in arctic bottom communities (Scheibling and Hatcher 2013). This includes the extensive Svalbard rhodolith beds (Teichert et al. 2012, 2014), where members of the genus Strongylocentrotus play a major role in biosedimentary processes as producers of biogenic carbonate, as grazers, and as primary triggers of epibenthos disturbance and dislocation of rhodoliths (Wisshak et al. 2019).

\section{Materials and methods}

The design of the SaM lander and the methodological approach during image analysis was described in depth in Wisshak et al. (2019) and is briefly summarised in the following account. The lander was deployed for a 6-day period in June 2016 during Maria S. MERIAN cruise 55 in Mosselbukta, Spitsbergen, at $79^{\circ} 54.69^{\prime} \mathrm{N} / 15^{\circ} 48.72^{\prime} \mathrm{E}$ in $46 \mathrm{~m}$ water depth. The lander carried a number of sensors and autonomous data loggers, as well as an Ocean Imaging Systems (OIS) camera system. Illumination was provided by a bare bulb flash opposite of a large reflector. The camera, pointing straight down, was released in 10-min intervals, repeatedly capturing the same $86 \times 57 \mathrm{~cm}$ of seafloor. After recovery, the OIS images were batch-processed in Adobe Lightroom (v. 5.7.1) with regard to exposure control, white balancing, removal of chromatic aberrations, and slight sharpening. Mobility analysis of the sea urchins was performed with ImageJ (v. 1.46) in combination with the 'manual tracking' plugin. The results include the distance travelled by each object between two slices and the resulting speed, both to be considered conservative estimates due to incremental tracks lacking a vertical component. In addition, the diameter of each sea urchin was determined using the 'measurements' tool in ImageJ.

Additionally, a collection query in the echinoderm collection of the Berlin Natural History Museum has been conducted to trace repair features in the tests of both fossil and recent sea urchins.

\section{Results and discussion}

One of the tracked Strongylocentrotus, an adult individual measuring $38 \mathrm{~mm}$ in diameter (track \# 22 in the animated image stack provided with the supplementary online material for Wisshak et al. (2019: Supplementary video S2), caught our attention in that it showed severe damage to the apical region of its corona, about half of which was missing, exposing the intestines and the jaw apparatus or Aristotle's lantern (Fig. 1). Despite this presumably fatal injury, including the loss of the madreporite, gonads and anus, the urchin did continue to move across the rhodolith bed for a documented interval of $43 \mathrm{~h}$ and $20 \mathrm{~min}$. During that time it travelled a cumulative distance of more than $60 \mathrm{~cm}$, which is above average regarding the tracked specimens. Given the fact that the sea urchin appears on the scene already injured (Fig. 1b) we neither know the exact timing nor the reason for the injury. The observed damage may have had a natural cause, most likely the predatory attack by a fish or large crustacean, an interpretation that is reinforced by the fact that the sea urchin's gonads-target of most sea urchin predators (Himmelman and Steele 1971) — are missing. Or, it might have been us scientists who caused the injury by accident when deploying and documenting the lander platform, 79:30 and 78:40 h, respectively, before the victim came into view of the lander's camera system. In the latter case, the survival time would increase to more than 6 days. The snapshots taken in 10-min intervals did capture another incidence of predation when a great spider crab Hyas araneus attacked the sea urchin (Fig. 1d), removing some of the remaining intestines and triggering it to escape and to move in a circle (Fig. 1e), thus evidencing that the animal was still capable of actively reacting to such disturbance. After this documented attack, the inner surface of half of the lower corona, including the jaw apparatus, was exposed blank, but the sea urchin continued to move little ways or to turn (Fig. 1f), and it kept moving its spines until the very last frame shot during the lander deployment (Fig. 1g). Whether the individual was able to recover from the documented severe injury, despite having lost even the madreporite without which the ambulacral vascular system is compromised, remains unknown.

Large adult Strongylocentrotus are prey to a variety of durophagous predators, namely lobsters (Homarus spp.), crabs (Brachyura) and wolf-fish (Anarhichas lupus) (Hagen and Mann 1992; Scheibling and Hatcher 2013). To gain access to the soft body, these predators break the sea urchin test either with their chelae or with their teeth, causing large traumatic openings which are in most cases lethal (Himmelman and Steele 1971). The fact that the heavily damaged Strongylocentrotus urchin exhibited locomotory 


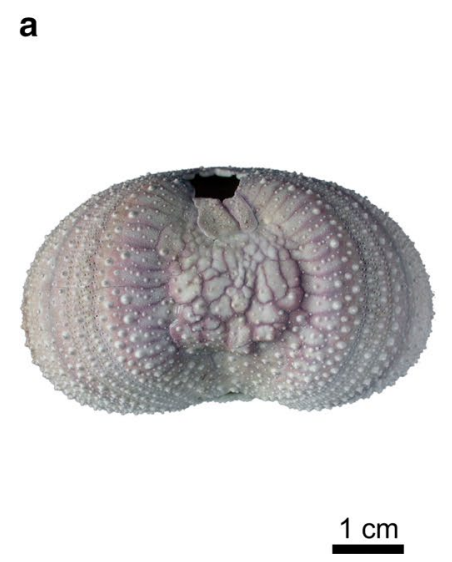

\begin{abstract}
b
\end{abstract}

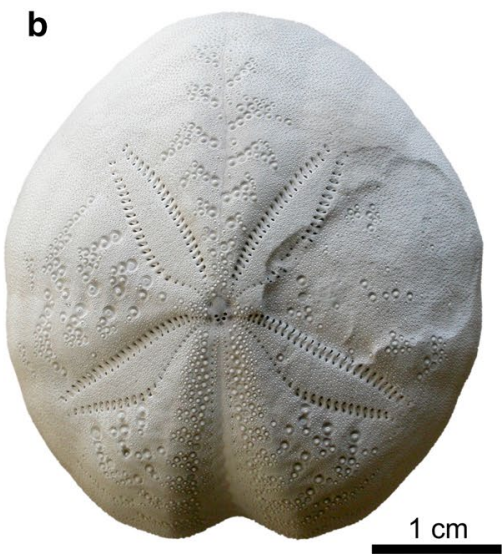

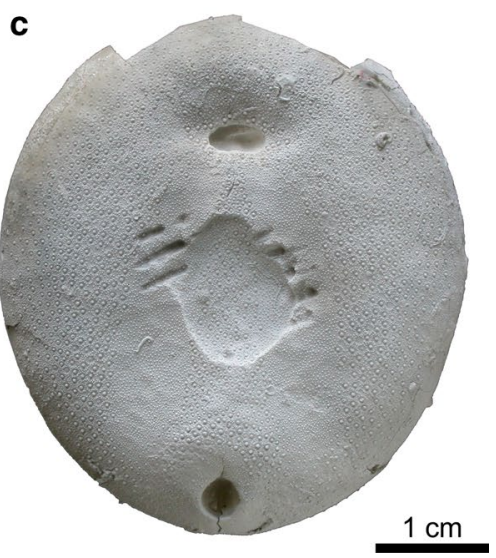

Fig. 2 A selection of examples of extant and fossil sea urchin tests with complete regeneration after severe predatory damage, illustrating the resilience and these echinoderms to injury. a. Tripneustes gratilla (Toxopneustidae), extant, Indopacific (Dar es Salaam, Tanzania) with healed ambital fracture exhibiting irregular arrangement of newly formed plates. b. Spatangus purpureus (Spatangidae), extant,
Mediterranean Sea (Hvar, Croatia) with large regenerated fracture of adapical interambulacrum 2. c Echinocorys ovata (Echinocorythidae), fossil, Late Cretaceous of Hemmoor (Germany) showing regenerated predatory damage of the plastron and related biting traces (all specimens from the collections of the Natural History Museum Berlin) behaviour including response to disturbance (crab attack) is owed to the peculiarity of its nervous system. Echinoderms possess a primitive and decentralised nervous system which is separated into an ectoneural and a hyponeural system with limited neural connections between them (Mashanov et al. 2009, 2016). Apart from a circumoral nerve ring as the most centralised nervous structure, they possess no brain to which all sensory input converges and from which motor commands emerge (Stiefel and Barrett 2018). Strongylocentrotus moves either on its tube feet or spines (Laur et al. 1986) and movement of spine muscles is maintained by the ectoneural nervous system which is situated in the epithelium as a subepidermal plexus, whereas coordinated movement necessary for locomotion is ensured by the circumoral nervous ring (Hyman 1955; Strenger 1973; Stiefel and Barrett 2018). Both large parts of the subepidermal plexus and the circumoral nervous ring remained intact after the traumatic event, explaining why the urchin was still able to move around.

Sea urchins are able to survive and to repair large traumatic injuries of the test, as illustrated by extant and fossil specimens with healed fractures (Fig. 2). First described by Okada (1926) and confirmed by Ameye and Dubois (1995), experimentally produced test damage to regular sea urchins is closed in centripetal manner after few days with clotting coelomocytes. During the following weeks, this quick repair process is continued by the formation of a more differentiated epithelium. The regeneration is completed after approximately six weeks when a calcified skeleton has been formed. The duration of this process may vary significantly between species and specimens, due to dependence on many intrinsic and extrinsic factors (Bonasoro et al. 2004; Henry and Hart 2005). For instance, it remains still unknown how large an injury of the test needs to be to become lethal; in some species, even small lesions may become moribund when infectious bacteria enter the coelomic cavity (Bauer and Young 2000). Although it remains unresolved to us if the sea urchin died from his wounds shortly afterwards or continued to live, the present observations underline the vital force of this representative of the genus Strongylocentrotus which is capable to survive severe skeletal damage for a time span presumably long enough for regeneration processes to be initiated. Apart from that, members of the genus can reach a remarkable longevity, with $S$. droebachiensis reaching 25 years (Robinson and MacIntyre 1997), whereas for S. pallidus, a maximum age of 42 years has been postulated (Bluhm et al. 1998). Their close relative $S$. franciscanus that lives along the west coast of North America reportedly even lives for longer than a century (Ebert and Southon 2003).

The importance of tissue regeneration as an antipredatory trait was emphasised by Vermeij (1982), who pointed out that survival of unsuccessful predation is a necessary condition for the evolution of antipredatory characteristics. In other words, selection in favour of antipredatory traits can occur only when some members of a prey population survive to reproduce after being assaulted by a predator. Our examination of both fossil and extant sea urchin tests from museum collections suggests that successful repair of even large skeletal damages is a common phenomenon and occurs at least since the Mesozoic era.

Acknowledgements Open Access funding provided by Projekt DEAL. Research permits were issued by The Norwegian Petroleum Directorate (Ref \#: OD 15/1045-/HeHa), The Directorate of Fisheries (Ref \#: 
15/14719) and the Norwegian National Joint Headquarters. The 'SaM Lander' was designed, built and deployed with support of the technicians Maik Wilsenack and Ralf Kuhlmann (Senckenberg am Meer, Wilhelmshaven), and the integrated Ocean Imaging Systems was kindly contributed by Peter Linke (GEOMAR-Helmholtz Centre for Ocean Research, Kiel). The M. S. MERIAN cruise MSM55 gratefully relied on the commitment of Captain Ralf Schmidt and the entire crew. We appreciatively acknowledge the valuable comments and suggestions by the editor and two anonymous reviewers.

Funding The M. S. MERIAN cruise MSM55 was funded by the Deutsche Forschungsgemeinschaft in concert with the Leitstelle Deutsche Forschungsschiffe. Additional funding for the development of the lander was kindly provided by André Freiwald (Senckenberg am Meer, Wilhelmshaven).

\section{Compliance with ethical standards}

Conflict of interest The authors declare that they have no conflict of interest.

Open Access This article is licensed under a Creative Commons Attribution 4.0 International License, which permits use, sharing, adaptation, distribution and reproduction in any medium or format, as long as you give appropriate credit to the original author(s) and the source, provide a link to the Creative Commons licence, and indicate if changes were made. The images or other third party material in this article are included in the article's Creative Commons licence, unless indicated otherwise in a credit line to the material. If material is not included in the article's Creative Commons licence and your intended use is not permitted by statutory regulation or exceeds the permitted use, you will need to obtain permission directly from the copyright holder. To view a copy of this licence, visit http://creativecommons.org/licenses/by/4.0/.

\section{References}

Ameye L, Dubois P (1995) Resorption and calcification during regeneration of the echinoid test. In: Emson R, Smith A, Campbell A (eds) Echinoderm Research 1995: Proceedings of the Fourth European Echinoderms Colloquium, London, 10-13 April 1995. A.A. Balkema, Rotterdam, pp 231-235

Anisimova NA, Cochrane SJ (2003) An annotated checklist of the echinoderms of the Svalbard and Franz Josef Land archipelagos and adjacent waters. Sarsia 88:113-135

Bauer JC, Young CM (2000) Epidermal lesions and mortality caused by vibriosis in deep-sea Bahamian echinoids: a laboratory study. Dis Aquat Org 39:193-199

Bluhm BA, Piepenburg D, von Juterzenka K (1998) Distribution, standing stock, growth, mortality and production of Strongylocentrotus pallidus (Echinodermata: Echinoidea) in the northern Barents Sea. Polar Biol 20:325-334

Bonasoro F, Ferro P, Di Benedetto C, Sugni M, Mozzi D, Carnevali MC (2004) Regenerative potential of echinoid test. In: Heinzeller T, Nebelsick JH (eds) Echinoderms: München. Proceedings of the 11th International Echinoderm Conference, 6-10 October 2003. CRC Press, Munich, p 97

Dubois P, Ameye L (2001) Regeneration of spines and pedicellariae in echinoderms: a review. Microsc Res Tech 55:427-437

Ebert TA (1967) Growth and repair of spines in the sea urchin Strongylocentrotus purpuratus (Stimpson). Biol Bull 133:141-149

Ebert TA, Southon JR (2003) Red sea urchins (Strongylocentrotus franciscanus) can live over 100 years: confirmation with A-bomb 14carbon. Fish B-NOAA 101:915-922
Gagnon JM, Gilkinson KD (1994) Discrimination and distribution of the sea urchins Strongylocentrotus droebachiensis (O.F. Müller) and S. pallidus (G.O. Sars) in the Northwest Atlantic. Sarsia 79:1-11

Hagen NT, Mann KH (1992) Functional response of the predators American lobster Homarus americanus (Milne-Edwards) and Atlantic wolffish Anarhichas lupus (L.) to increasing numbers of the green sea urchin Strongylocentrotus droebachiensis (Müller). J Exp Mar Biol Ecol 159:89-112

Heatfield BM, Travis DF (1975) Ultrastructural studies of regenerating spines of the sea urchin Strongylocentrotus purpuratus. II Cell types with spherules. J Morphol 145:51-71

Henry LA, Hart M (2005) Regeneration from injury and resource allocation in sponges and corals - a review. Int Rev Hydrobiol 90:125-158

Himmelman JH, Steele DH (1971) Foods and predators of the green sea urchin Strongylocentrotus droebachiensis in Newfoundland waters. Mar Biol 9:315-322

Hyman LH (1955) The invertebrates Vol. IV: Echinodermata. McGrawHill, New York

Jensen M (1974) The Strongylocentrotidae (Echinoidea), a morphologic and systematic study. Sarsia 57:113-148

Khadra YB, Sugni M, Ferrario C, Bonasoro F, Oliveri P, Martinez P, Carnevali MDC (2018) Regeneration in stellate echinoderms: Crinoidea, Asteroidea and Ophiuroidea. In: Kloc M, Kubiak JZ (eds) Marine organisms as model systems in biology and medicine. Springer, Heidelberg, pp 285-320

Laur DR, Ebeling AW, Reed DC (1986) Experimental evaluations of substrate types as barriers to sea urchin (Strongylocentrotus spp.) movement. Mar Biol 93:209-215

Lawrence JM, Vasquez J (1996) The effect of sublethal predation on the biology of echinoderms. Oceanol Acta 19:431-440

Mashanov VS, Zueva OR, Heinzeller T, Aschauer B, Naumann WW, Grondona JM, Cifuentes M, Garcia-Arraras JE (2009) The central nervous system of sea cucumbers (Echinodermata: Holothuroidea) shows positive immunostaining for a chordate glial secretion. Front Zool 6:11

Mashanov V, Zueva O, Rubilar T, Epherra L, Garcia-Arraras JE (2016) Echinodermata. In: Schmidt-Rhaesa A, Harzsch S, Purschke G (eds) Structure and evolution of invertebrate nervous systems. Oxford University Press, Oxford, pp 665-688

Okada YK (1926) Über die Regeneration bei Seeigeln. Wilhelm Roux' Archiv für Entwicklungsmechanik der Organismen 108:487-489

Palerud R, Gulliksen B, Brattegard T, Sneli JA, Vader W (2004) The marine macro-organisms in Svalbard waters. A catalogue of the terrestrial and marine animals of Svalbard. Norsk Polarinstt Skri 201:5-56

Robinson SMC, MacIntyre AD (1997) Ageing and growth of the green sea urchin. Bull Aquac Assoc Can 91:56-60

Scheibling RE, Hatcher BG (2013) Strongylocentrotus droebachiensis. In: Lawrence JM (ed) Sea urchins: biology and ecology Developments in Aquaculture and Fisheries Science. Elsevier, Amsterdam, pp 381-412

Stiefel K, Barrett G (2018) Sea urchins as an inspiration for robotic designs. J Mar Sci Eng 6:112

Strenger A (1973) Sphaerechinus granularis (Violetter Seeigel), Anleitung zur makroskopischen und mikroskopischen Untersuchung. In: Siewing R (ed) Großes zoologisches Praktikum, vol 18. Fischer, Stuttgart, pp 1-68

Teichert S, Woelkerling W, Rüggeberg A, Wisshak M, Piepenburg D, Meyerhöfer M, Form A, Büdenbender J, Freiwald A (2012) Rhodolith beds (Corallinales, Rhodophyta) and their physical and biological environment at $80^{\circ} 31^{\prime} \mathrm{N}$ in Nordkappbukta (Nordaustlandet, Svalbard Archipelago, Norway). Phycologia 51:371-390

Teichert S, Woelkerling W, Rüggeberg A, Wisshak M, Piepenburg D, Meyerhöfer M, Form A, Freiwald A (2014) Arctic rhodolith beds and their environmental controls (Spitsbergen, Norway). Facies $60: 15-37$ 
Vermeij GJ (1982) Unsuccessful predation and evolution. Am Nat 120:701-720

Wisshak M, Neumann H, Rüggeberg A, Büscher JV, Linke P, Raddatz J (2019) Epibenthos dynamics and environmental fluctuations in two contrasting polar carbonate factories (Mosselbukta and BjørnøyBanken, Svalbard). Front Mar Sci. https://doi.org/10.3389/fmars .2019 .00667
Publisher's Note Springer Nature remains neutral with regard to jurisdictional claims in published maps and institutional affiliations. 